Vol.48, Special : pp. 45-49, October 2005 ISSN 1516-8913 Printed in Brazil
BRAZILIAN ARCHIVES OF BIOLOGY AND TECHNOLOGY

AN INTERNATIONAL JOURNAL

\title{
Assessment of Bacterial Translocation in Obstructive Jaundice Using Tc-99m Escherichia coli
}

\author{
Simone Odília Fernandes Diniz ${ }^{1 *}$, Alfredo José Afonso Barbosa ${ }^{2}$ : Ivana Durval Araújoº, \\ David Lee Nelson ${ }^{1}$, Leonardo Augusto da Silva Machado ${ }^{2}$, Mário Bernardo Filho ${ }^{3}$ and \\ Valbert Nascimento Cardoso ${ }^{1}$ \\ ${ }^{1}$ Faculdade de Farmácia; ${ }^{2}$ Faculdade de Medicina; Universidade Federal de Minas Gerais; \\ simone@farmacia.ufmg.br; Belo Horizonte - MG - Brasil. ${ }^{3}$ Departamento de Biofísica e Biometria; Universidade \\ Estadual do Rio de Janeiro; Rio de Janeiro - RJ - Brasil
}

\begin{abstract}
In obstructive jaundice, the passage of bacteria and endotoxins through the intestine wall to reach the systemic circulation is associated with septicemia, renal failure and pulmonary dysfunction. The aim of this work was to investigate bacterial translocation utilizing ${ }^{99 m}$ Tc-E.coli in an experimental model of obstructive jaundice. The levels of bilirubin in rats that were subjected to ligature of the bile duct were significantly increased when compared to control animals $(p<0.001)$. The biodistribution results did not show any translocation of ${ }^{99 m}$ Tc-E.coli to the mesenteric lymphatic nodules, liver, spleen or lungs of the rats that suffered ligature of the bile duct $(p>0.05)$. The evaluation of the intestinal permeability using "per os" administration of ${ }^{99 m}$ Tc-DTPA showed $1.61 \pm 0.57 \%$ and $1.39 \pm 0.72 \%$ of radioactivity in the urine of the control and jaundice animals, respectively. The histological analysis of the distal wall of the ileum showed that the covering epithelium and the crypt were morphologically preserved in both groups. The seven-day period after the ligature of the bile duct may not have been long enough to promote modifications in intestinal wall to occur so as to permit the passage of Tc-99m E.coli.
\end{abstract}

Key words: Bacterial translocation, Technetium-99m E coli, obstructive jaundice

\section{INTRODUCTION}

Jaundice is characterized by an increase in the bilirubin level in blood serum and by a yellowing of the sclera, mucosa, skin and body liquids (Rosa, 1993). Among the principal types of jaundice, obstructive jaundice, caused by an obstruction of the bile ducts, can be singled out. This obstruction is normally caused by a blockage of the coledochus by bile calculous, stenosis or by carcinoma in the pancreas and gall bladder (Guyton, 2002).
Patients with obstructive jaundice are susceptible to septicemia, renal failure and pulmonary dysfunction. The explanation for this susceptibility is based on the fact that bacteria and endotoxins can pass through the intestine wall and reach the systemic circulation, a phenomenon known as bacterial translocation (Pitt et al., 1981; Reynolds et al., 1996; Steinberg, 2003).

Bacterial translocation is defined as the passage of viable enteric bacteria and endotoxins through the intestinal barrier, leading to bacteremia and septicemia (Berg and Garlington, 1979; Alexander et al., 1990). This phenomenon has been evaluated

\footnotetext{
*Author for correspondence
} 
in experimental models where the quantification of bacteria present in the mesenteric lymphatic nodules (MLN), liver, spleen and lungs is determined principally by microbial culture techniques (Guo et al., 1994; Reynolds et al., 1995). The principal microorganisms found in these organs correspond to anaerobic gramnegative and facultative anaerobic bacili, Escherichia coli being the bacteria most frequently encountered (Steffen et al., 1988; Deitch, 1989). The work described here proposed to investigate bacterial translocation in an experimental model of obstructive jaundice employing ${ }^{99 \mathrm{~m}}$ Technetium labeled Escherichia coli.

\section{Labeling of $E$. coli with ${ }^{99 \mathrm{~m}}$ Technetium}

The labelling of $E$. coli with ${ }^{99 \mathrm{~m}}$ Technetium was performed according to the procedure described by Diniz et al, 1999. Briefly, 2.0-mL aliquots of the bacterial suspension were incubated at $37{ }^{\circ} \mathrm{C}$ with $580 \mu \mathrm{M}$ stannous chloride, $\mathrm{pH} 7.0$, for ten minutes. Then 15.0 to $74 \mathrm{MBq}$ of ${ }^{99 \mathrm{~m}}$ Tecnetium was added to each preparation and maintained at $37{ }^{\circ} \mathrm{C}$ for another ten minutes. After centrifugation, $100-\mu \mathrm{L}$ aliquots of the supernatant and precipitate were removed for determination of the labeling yield.

\section{Experimental model of obstructive jaundice}

Wistar rats, 250-350 g, were anesthetized with a mixture of Rompun ${ }^{\circledR}(12.5 \mathrm{mg} / \mathrm{kg})$ and Dopalen ${ }^{\circledR}$ $(1.25 \mathrm{mg} / \mathrm{kg})$ administered intraperitonially. A central incision of approximately eight centimeters was made in the abdomen of the animals. The common bile duct (CBD) was ligated with a polyglycolic acid (Dexon ${ }^{\circledR}$ ) 4-0 and sectioned between the ligatures. The animals were then anesthetized and the blood was collected from the lower vena cava for bilirubin determination. The animals of the sham group (simulated surgery) were submitted to the same surgical stress. Seven days after the surgery, the animals of the sham and CBD groups were used in the bacterial translocation and intestinal permeability studies.

\section{Determination of Total Bilirubin}

Bilirubin was determined in samples of serum from CBD group $(n=16)$ and sham group $\quad(n=$ 16) rats employing reagent kits furnished by Quibasa.

\section{Bacterial translocation studies}

Alíquots of $0.2 \mathrm{~mL}$ of Tc-99m E. coli $(1.6 \mathrm{MBq})$ were administered "per os" to sham group $(\mathrm{n}=10)$ and CBD group $(\mathrm{n}=10)$ rats. The animals were kept in metabolic cages for 24 hours with feed and water ad libitum. The animals were anesthetized as described above and the mesenteric lymphatic nodules (MLN), liver, spleen, lung, stomach, and the small and large intestines were removed, washed and weighed, and the radioactivity was determined. The feces were collected during the 24-hour period for determination of the excreted radioactivity.

\section{Determination of the intestinal permeability}

Alíquots of $0.2 \mathrm{~mL}$ of ${ }^{99 \mathrm{~m}}$ Tc-DTPA (1.6 MBq) were administered "per os" to CBD $(\mathrm{n}=6)$ and sham $(n=6)$ rats. The animals were then placed in metabolic cages and maintained for 24 hours with food and water ad libitum. After that, the animals were anesthetized and blood was collected for biochemical analyses. The urine and feces collected during the 24-hour period were collected for determination of radioactivity.

The results obtained in the study of bacterial translocation and intestinal permeability were expressed as the percentage of the administered dose (\% of dose per organ).

The percentage of administered dose was calculated using the following equation:

$$
\% \text { administrated dose }=\frac{\text { cpm per organ }}{\text { cpm reference }} \times 100
$$

\section{Histological analysis}

The animals were sacrificed, fragments of the ileum were removed, fixed with $4 \%$ formaldehyde solution and coated with paraffin according to the normal procedure. Five $\mu \mathrm{m}$ slices were obtained from each fragment and were stained with hematoxylin and eosine (HE) for histological analyses.

\section{Statistical analysis}

The results were evaluated by the Student $t$ test for independent samples. The differences were considered statistically significant for values of $\mathrm{p} \leq 0.05$. 


\section{RESULTS}

As can be seen in Fig. 1, the total bilirubin values of CBD group rats were significantly greater than those of the sham group, the differences being considered statistically significant for values of $p$ $\leq 0.05$. The data in Table 1 show that $90 \%$ of the administered dose had been eliminated in the feces 24 hours after administration of Tc-99m E.coli and that $9 \%$ still remained in the gastrointestinal tract of the sham and CBD rats. There was hardly any uptake of Tc-99m E.coli by the liver, spleen and lung, there being no significant difference between the sham and CBD rats in the biological distribution of Tc-99m E.coli. There was no significant difference in the percentages of ${ }^{99 \mathrm{~m}} \mathrm{Tc}$ DTPA present in the feces of the sham and CBD rats. There was also no significant difference in the percentages of ${ }^{99 \mathrm{~m}} \mathrm{Tc}$-DTPA eliminated in the urine of the same rats.

The histological exam of slices of the ileum wall did not show any differences between the sham and CBD groups. The covering epithelium and the crypts were morphologically preserved in both groups (Fig. 2a and b)

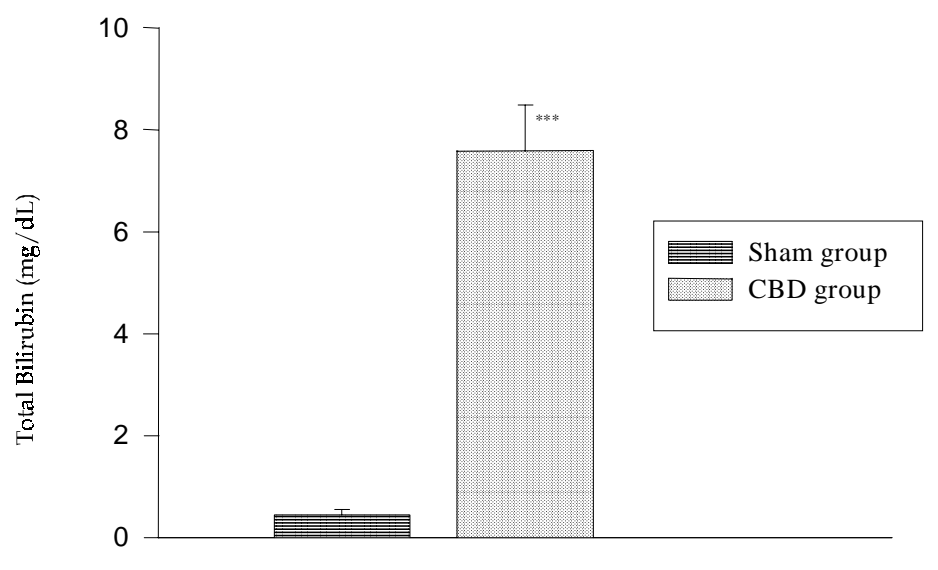

Figure 1- Dosage of Total bilirubin

Values expressed as the mean $\pm \mathrm{sd}, \mathrm{n}=32(* * * \mathrm{p}<0,001)$

Table 1 - Biodistribution studies 24 hours after administration of Tc-99m E.coli "per os".

\begin{tabular}{lcc} 
& Sham (\% dose) & CBD (\% dose) \\
\hline Liver & & $0.02 \pm 0.01$ \\
Spleen & $0.02 \pm 0.01$ & $0.003 \pm 0.001$ \\
Lungs & $0.004 \pm 0.001$ & $0.002 \pm 0.001$ \\
MLN ${ }^{1}$ & $0.004 \pm 0.002$ & nd \\
SLI & nd & $10.44 \pm 1.99$ \\
Feces & $8.93 \pm 0.85$ & $89.50 \pm 10.30$ \\
Values expressed as the mean \pm sd, $\mathrm{n}=10(\mathrm{p} \geq 0.05)$ & \\
CBD - common bile duct & & \\
MLN- mesenteric lymph node & & \\
SLI- stomach, small and large intestines. & & \\
nd - not detected &
\end{tabular}


Table 2 - Intestinal permeability studies 24 hours after "per os" administration of ${ }^{99 \mathrm{~m}}$ Tc-DTPA

\begin{tabular}{ccc}
\hline & Sham $(\%$ dose) & CBD (\% dose) \\
\hline $\begin{array}{c}\text { Urine } \\
\text { (accumulated) } \\
\text { Feces } \\
\text { (accumulated) }\end{array}$ & $1.61 \pm 0.57$ & $1.39 \pm 0.72$ \\
\hline
\end{tabular}

Values expressed as the mean $\pm s d, n=6(p \geq 0.05)$.
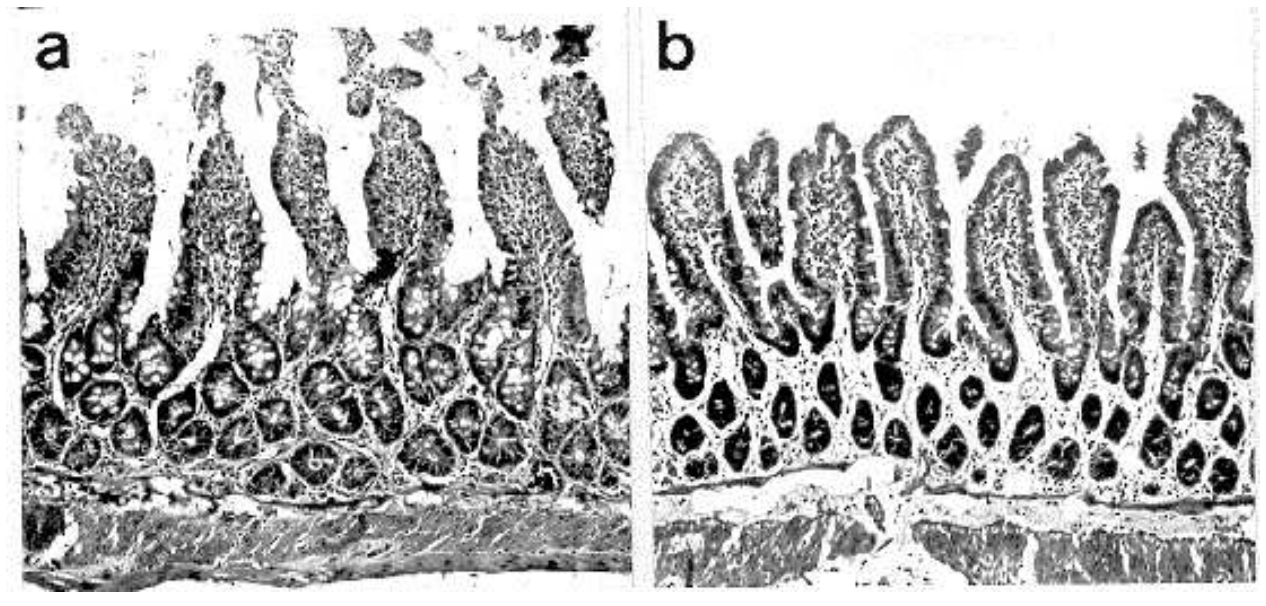

Figure 2 - Histological studies of the distal ileum wall from a mouse (a) sham animal; (b) CBD animal seven days after suture of the common bile duct.

\section{DISCUSSION}

The experimental model of obstructive jaundice consisted of sectioning the common bile duct of the rats so that the bile duct did not reach the intestine, thus promoting a process of cholestasis. According to Rosa (1993), jaundice is characterized by an increase in the bilirubin levels in the serum. The results obtained in this work showed significant increases in bilirubin levels (p $<0,001)$, an observation that indicated that the animals became jaundiced seven days after ligature of the bile duct.

The results for bacterial translocation demonstrated that the uptake of Tc-99m E.coli by mesenteric lymphatic nodules, liver, spleen and lungs of CBD rats were not significantly different from those of the control rats. These data indicate that Tc-99m E. coli did not pass from the gastrointestinal tract to the extra-intestinal organs. These data were reinforced by the observation that approximately $99.9 \%$ of all the radioactivity was present in the feces, stomach, and small and large intestines 24 hours after administration.

Resnick et al. (1990) demonstrated that there was an increase in the intestinal permeability of patients with gastrointestinal diseases by measuring the increase in ${ }^{99 \mathrm{~m}} \mathrm{Tc}$-DTPA and ${ }^{51} \mathrm{Cr}$ EDTA excreted in the urine during 24 hours by these patients. The results for intestinal permeability obtained in the present work showed that there was no significant difference in the percentage of ${ }^{99 \mathrm{~m}} \mathrm{Tc}$-DTPA eliminated in the urine during 24 hours by the sham group $(1.61 \pm 0.57)$ and CBD group $(1.39 \pm 0.72)$ rats. These data indicate that there was no increase in the intestinal permeability of the jaundiced rats, a fact that supports the hypothesis that the intestinal barrier is preserved, impeding the passage of Tc-99m E.coli to the MLN, liver, spleen and lungs. In addition, no differences were observed between the sham and CBD groups in the histological examination of the slices of the ileum wall. The covering epithelium and crypts were morphologically preserved in both groups, an observation that also 
corroborates the fact that there was no alteration of the intestinal wall that would allow translocation of bacteria.

It could be that the seven-day period after the ligature of the bile duct may not have been sufficient for a modification of the intestinal wall to a degree that would permit the passage of bacteria. The results of the histological analyses of the ileum and the permeability tests of the present work reinforce this hypothesis.

\section{ACKNOWLEDGEMENTS}

The authors thank FAPEMIG for the financial support

\section{RESUMO}

$\mathrm{Na}$ icterícia obstrutiva, a passagem de bactérias e endotoxinas através da parede intestinal alcançando a circulação sistêmica está associada com septicemia, falência renal e disfunção pulmonar. A proposta deste trabalho foi investigar a translocação bacteriana, empregando a Tc-99m E.coli, em um modelo experimental de icterícia obstrutiva. Os níveis de bilirrubina nos ratos que sofreram a ligadura do ducto biliar estavam significativamente aumentados quando comparados com os valores dos animais controles $(\mathrm{p}<0,001)$. Os resultados de biodistribuição não mostraram translocação da Tc-99m E.coli para os nódulos linfáticos mesentéricos, fígado, baço e pulmões dos ratos que sofreram ligadura do ducto biliar ( $p>0,05)$. A avaliação da permeabilidade intestinal usando a administração "per os" de ${ }^{99 \mathrm{~m}}$ Tc-DTPA mostrou um percentual de eliminação deste radiofármaco na urina de $1,61 \pm 0,57 \mathrm{e}$ $1,39 \pm 0,72$ para os animais controles e ictéricos, respectivamente. A análise histológica da parede distal do íleo mostrou que tanto o epitélio de revestimento quanto as criptas apresentaram morfologicamente conservados em ambos os grupos. O tempo transcorrido, 7 dias, após a ligadura do ducto biliar talvez não tenha sido longo o suficiente para promover modificações na parede intestinal de modo a permitir a passagem da ${ }^{99 \mathrm{~m}} \mathrm{Tc}-$ E.coli.

\section{REFERENCES}

Alexander, J. W.; Boyce, S. T.; Babcock, G. F.; Gianotti, L.; Peck, M. D.; Dunn, D. L.; Pyles, T.;Childress, C. P. and Ash, S. K. (1990), The process of microbial translocation. Ann. Surg., 212, 496-512.

Berg, R. D. and Garlington, A. W. (1989), Translocation of certain indigenous bacteria from the gastrointestinal tract to the mesenteric limph nodes and other organs in a gnotobiotic mouse model. Infect. Immun., 23, 403-411.

Deitch, E. A. (1989), Simple intestinal obstruction causes bacterial translocation in man. Arch. Surg., 124, 699-701.

Diniz, S. O. F.; Resende B. M.; Nunan E. A.; Simal, C. J. R. and Cardoso, V. N. (1999), ${ }^{99 m-}$ Technetium labelled Escherichia coli. Appl Radiat Isot, 51, 33-6.

Guo, W.; Andersson, R.; Willén, R.; Ljungh, A.; Wang,X.; Liu, X. and Bengmark, S. (1994), Bacterial translocation after intraperitoneal implantation of rubber fragments in the splenectomized rat. J. Surg. Res., 57, 408-415.

Guyton, A. C.; Hall, J. E. (2002), Tratado de fisiologia médica. Rio de Janeiro : Guanabara-Koogan.

Pitt, H. A.; Cameron, J. L.; Postier, R. G. and Gadacz, T. R. (1981), Factors affecting mortality in biliary tract surgery. Am. J. Surg., 141, 66-72.

Resnick, R. H.; Royal, H.; Marshall, W.; Barron, R. and Werth, T. (1990), Intestinal permeability in gastrointestinal disorders. Use of oral $\left[{ }^{99 \mathrm{~m}} \mathrm{Tc}\right]$ DTPA. Dig. Dis. Sci., 35, 205-211.

Reynolds, J. V.; Murchan, P.; Leonard, N.; Clarke, P.; Keane, F. B. V. and Tanner, W. A. (1996), Gut barrier failure in experimental obstructive jaundice. J. Surg. Res., 62, 11-16.

Rosa, H. (1993), Síndromes hepáticas. InGastroenterologia clínica. ed. 3. Dani, R.; Castro, L.P. Guanabara-Koogan, Rio de Janeiro, pp. 11381154.

Steffen, E. K.; Berg, E. D. and Deitch, E. D. (1988), Comparison of translocation rates of various indigenous bacteria from the gastrointestinal tract to the mesenteric limph node. J. Infect. Dis., 157, 1032-1038.

Steinberg, S. M. (2003), Bacterial translocation: what it is and what it is not. Am. J. Surg., 186, 301-305.

Received: July 04, 2005; Revised: July 14, 2005; Accepted: August 01, 2005. 